\title{
Optimalisasi Peran Masyarakat Dalam Mekanisme Pencegahan Infeksi Covid-19 Dalam Program KKN Melalui Program Pendidikan Dan Kesehatan Di Kawasan Kabupaten Kulonprogo Dan Bantul
}

\author{
Okid Parama Astirin 1,2), Diastama Anggita Ramadhan ${ }^{4)}$ dan Rahning Utomowati ${ }^{2), 3)}$ \\ 1. PS Biologi, FMIPA, Universitas Sebelas Maret, Surakarta \\ 2. Pusat Penelitian Lingkungan Hidup, LPPM, Universitas Sebelas Maret, Surakarta \\ 3. PS Geografi, FKIP, Universitas Sebelas Maret, Surakarta \\ 4. Fakultas Hukum, Universitas Diponegoro, Semarang \\ email : parama_astirin@yahoo.com
}

\begin{abstract}
Selama pandemi Covid-19 di mana setiap orang disarankan untuk melakukan physical distancing, program KKN di Universitas Sebelas Maret (UNS) ditetapkan oleh Rektor untuk tetap berlangsung dengan sejumlah penyesuaian. Pelaksanaan KKN dilakukan di lokasi tempat tinggal masing-masing dengan dibimbing oleh 1 DPL (dosen Pembimbing Lapangan) dengan penugasan 20 orang mahasiswa. Pelaksanaan KKN era Covid 19 dilakukan dengan beberapa metode. Metode yang dilakukan oleh mahasiswa ada 2 macam yaitu metode secara daring, metode luring (namun tetap melakukan protokol kesehatan) dan metode penyampaian pesan melalui berbagai media tidak secara online (memasang poster, menyebarkan leaflet, memasang banner, memberikan penjelasan kepada masyarakat door to door). Secara umum, meskipun pelaksanaan dilakukan lebih banyak diselenggarakan daring, namun makna pembentukan karakter empati kepada masyarakat yang terdampak Covid 19 maupun lapisan masyarakat yang potensial menerima resiko tertular, dan memiliki peran startegis untuk membentuk karakter mahasiswa. Kegiatan ini memiliki banyak manfaat bagi masyarakat melalui berbagai bentuk bantuan oleh mahasiswa peserta KKN
\end{abstract}

Kata Kunci: KKN era Covid 19, Thema Kesehatan Masyarakat, Kawasan Yogyakarta

\section{Pendahuluan}

Persoalan Covid-19 tidak hanya terjadi di Indonesia, namun dialami oleh banyak negara di dunia. Covid-19 merupakan permasalahan kesehatan, yang berdampak pada banyak sektor, salah satunya sektor ekonomi. Kesulitan akibat pandemi juga dirasakan bukan hanya oleh sektor swasta saja, melainkan sektor pemerintah juga, terutama dalam hal realisasi penyerapan rencana anggaran yang telah direncanakan tahun lalu. Di tengah pandemi Covid- 19 yang menyulitkan, harapan pergerakan ekonomi dari sektor non pemerintah itu sangat berat. Maka, optimalisasi belanja pemerintah menjadi salah satu upaya penting untuk menggerakkan roda perekonomian negara Indonesia agar tidak jatuh pada risiko kelumpuhan ekonomi

Selama pandemi Covid-19 di mana setiap orang disarankan untuk melakukan physical distancing, program KKN di Universitas Sebelas Maret (UNS) ditetapkan oleh Rektor untuk tetap berlangsung dengan sejumlah penyesuaian. Pelaksanaan KKN dilakukan di lokasi tempat tinggal masing-masing dengan dibimbing oleh 1 DPL (dosen Pembimbing Lapangan) dengan penugasan 20 orang mahasiswa. Setiap mahasiswa dapat memililih salah satu dari 8 skema pelaksanaan $\mathrm{KKN}$ atau dapat menambahkan program bila memang dirasakan perlu. Proses pendaftaran diawali dengan pengisian beberapa formulir yang dapat diunduh di laman UP KKNUNS, untuk kemudian di ikuti oleh mahasiswa yang sudah memenuhi syarat mengikuti KKN. KKN yang dilaksanakan periode Mei sd Juni 2020 wajib mendapatkan ijin dari orang tua mengingat dilaksanakan di era pandemi Covid. Proses yang diperlukan adalah melakukan pengisian pakta integritas untuk secara taat menerapkan protokol kesehatan sebagaimana yang telah diarahkan dalam buku saku yang diterbitkan. Universitas Sebelas Maret Surakarta menjadi pelopor program Kuliah Kerja Nyata atau KKN Era Covid-19 yang dilakukan mengutamakan proses secara daring. Dalam program ini, mahasiswa melakukan KKN secara mandiri dan tidak berkelompok di lokasi dimana mahasiswa berada. 
Jurnal SEMAR Vol. 10 No. 1, hal. $45-50$ ISSN: 2745-4223 | Copyright (C LPPM Universitas Sebelas Maret Homepage: https://jurnal.uns.ac.id/jurnal-semar

Pelaksanaan "KKN Era COVID-19 UNS Solo fokus pada tujuan KKN yang sejatinya untuk membantu masyarakat yang mengalami kesulitan dengan penyelesaian yang dibantu oleh mahasiswa dan DPL. Tema yang diprioritaskan dalam pelaksanaan program KKN Era Covid-19 yaitu kesehatan masyarakat, ketahanan ekonomi masyarakat, ketahanan pangan, edukasi, penyusunan sistem informasi, dan supporting keselamatan masyarakat terhadap Covid-19 pengabdian kepada masyarakat, menjaga diri dan turut serta memutus mata rantai Covid-19 di wilayah masing-masing dimana mahasiswa bertempat tinggal.

\section{Metode Pelaksanaan}

Pelaksanaan KKN era Covid 19 dilakukan dengan beberapa metode. Metode yang dilakukan oleh mahasiswa ada 2 macam yaitu metode secara daring, metode luring (namun tetap melakukan protokol kesehatan) dan metode penyampaian pesan melalui berbagai media tidak secara online (memasang poster, menyebarkan leaflet, memasang banner, memberikan penjelasan kepada masyarakat door to door). Pelaksanaan KKN UNS Era Covid- 19 batch II berlangsung sejak tanggal 15 Mei hingga 30 Juni 2020. Program yang dilaksanakan di RT 025 RW 013 dengan tema Supporting Pemahaman Masyarakat terhadap Covid-19 melalui 6 (enam) program yang dilaksanakan melalui berbagai kegiatan baik secara daring (online) maupun secara langsung terjun ke masyarakat dapat dikatakan efektif karena mulai dari perencanaan program, pelaksanaan program, hingga selesainya program pada tanggal 30 Juni 2020 dan berdurasi kurang lebih 130 jam telah berjalan dengan baik dan lancar.

Pelaksanaan sosialisasi tentang protokol kesehatan penanggulangan penyebaran virus covid 19 juga dilakukan secara offline namun tetap memperhatikan aspek sosial distancing dan physical distancing sehingga resiko penularan dapat dihindarkan. Pelaksanaan mekanisme peribadatan dilakukan penataan oleh para mahasiswa dengan dibantu oleh karang taruna dan takmir masjid. Pembuatan media sosialisasi dalam bentuk leaflet, poster, yang dibuat oleh para mahasiswa yang kemudian diletakkan di tempat strategis termasuk di lokasi peribadatan. Media lain juga dipergunakan oleh para mahasiswa melalui berita di instagram, facebook dan melalui video yang dihasilkan oleh para mahasiswa yang diunggah melalui media youtube.

Edukasi protokol kesehatan dilakukan baik ditingkat anak-anak usia Sekolah Dasar hingga kepada orangtua yang tinggal disekitar tempat tinggal mahasiswa pelaksana KKN UNS. Kelas khusus bagi murid SD dilakukan secara tatap muka tetapi tetap menjalankan protokol kesehatan yang sudah ditetapkan oleh Kemenkes (2000). Semua peserta diwajibkan cuci tangan sebelum masuk kelas dan menjaga jarak. Kelas membahas pengetahuan umum yang bisa diterima semua peserta. Seperti, edukasi mengenai COVID-19 dan penanaman budi pekerti melalui media video. Selain materi, terdapat aktivitas menarik lain dalam kelas agar peserta tidak bosan seperti quiz dan lomba menggambar. Di akhir pertemun, diberikan apresiasi berupa hadiah untuk peserta yang aktif selama pembelajaran. Kontak kepada anak- anak tingkat SD dilakukan karena beberapa anak tidak memiliki fasilitas untuk belajar secara online dengan guru.

Membuat grup di whatsapp untuk peserta kelas edukasi agar bisa memonitor kegiatan yang telah dilakukan. Grup whatsapp tersebut dibuat untuk memonitor peserta dan menginformasikan kelas. Selain itu, beberapa orang tua peserta juga ikut dalam grup ini untuk memonitor kegiatan anak-anak. Fasilitas tambahan di lokasi KKN juga telah diberikan dalam bentuk tempat untuk mencuci tangan dengan berbagai bentuk dan aneka bahan. Memberikan tutorial pembuatan hand sanitizer sekaligus membelikan bahan-bahannya. Melatih pembuatan masker sekaligus tutorial cara pemakaian yang benar. Membuat penanda jarak untuk tempat ibadah di masjid agar tidak berdesakan. Membuat perpustakaan kecil untuk memfasilitasi pelajar dalam menambah pengetahuan dan wawasan. Perpustakaan mini ini dibuat agar meningkatkan literasi penduduk. Buku perpustakaan desa didapatkan dari membeli dan dari donasi. Buku ditaruh di masjid agar bisa diakses semua warga. Buku ini terdapat beberapa macam seperti buku agama, buku anak-anak, dan buku pengetahuan umum. KKN-Covid 19 dilakukan selama kurang lebih 45 hari, program yang diberikan telah efektif sesuai dengan kebutuhan dan kemampuan masyarakat dalam menerima informasi, meskipun dalam beberapa hal belum efisien. Meski begitu bukan berarti tidak ada perubahan. 
Jurnal SEMAR Vol. 10 No. 1, hal. $45-50$

ISSN: 2745-4223 | Copyright (C LPPM Universitas Sebelas Maret Homepage: https://jurnal.uns.ac.id/jurnal-semar

\section{Hasil Dan Pembahasan}

Kegiatan KKN-Covid 19 sebagian besar dilaksanakan sesuai dengan program yang telah direncanakan di awal tetapi terjadi sedikit penyesuaian. Bentuk kegiatan yang terkait dengan peningkatan dan proteksi kesehatan masyarakat terhadap Pandemi Covid 19, yaitu:

\section{A. Sharing Informasi Tentang Covid-19 Via Sosial Media}

Program kerja yang pertama ini dilakukan dengan berbagai bentuk diantaranya adalah: tentang penjelasan tentang covid-19, cara penularan, orang yang rentan terhadap covid-19 serta tanda dan gejala covid19. Penjelasan tentang covid-19 dilakukan memutar video tentang cara mencegah penyebaran covid-19, tentang cara mencuci tangan dengan benar serta perbedaan Orang Tanpa Gejala (OTG), Orang dalam Pengawasan (ODP) dan Pasien Dalam Pengawasan (PDP), tentang new normal dan alasannya, menu makanan bergizi serta barang bawaan saat new normal. Informasi ini dibagikan di media sosial WAG (Whatshap Grup) RT RW setempat, WAG Karang Taruna, dan Instagram @ kkncovidgumelar yang ditujukan untuk masyarakat agar lebih mengenal covid-19 dan dapat melakukan pencegahan penyebaran dengan tepat. Dengan adanya sharing informasi ini masyarakat dapat memperoleh informasi yang valid karena sumber yang digunakan terpercaya seperti WHO. Respon dari masyarakat antusias, saat ada informasi mereka menangapi dan saling tukar informasi dan berbagi tips. Gambaran produk sosialisasi dalam bentuk leaflet, whatshap, instagram, youtube, facebook dapat ditunjukkan pada Gambar 1.

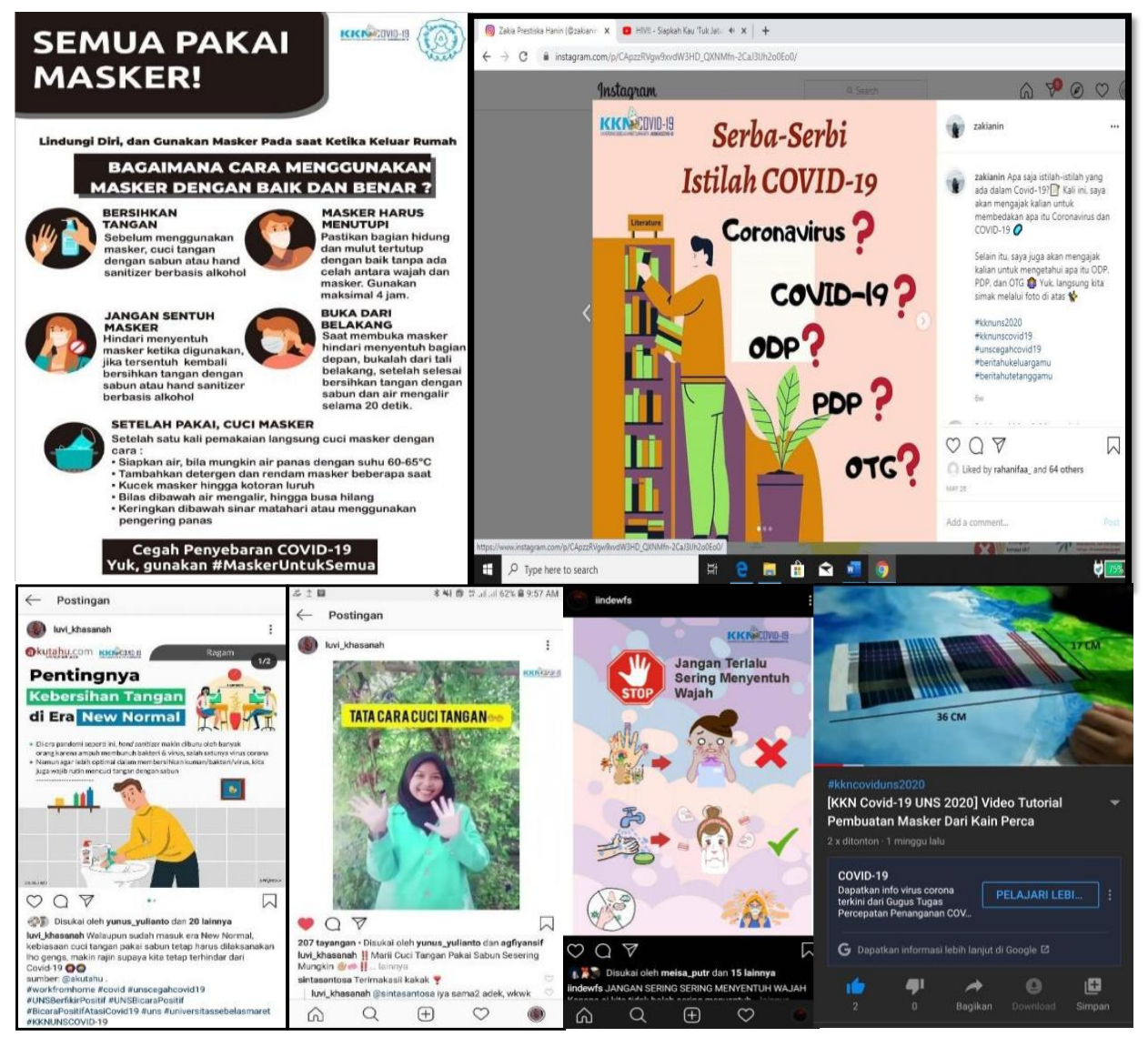

Gambar 1. Gambaran produk sosialisasi dalam bentuk leaflet, whatshap, instagram, youtube, facebook yang telah dilaksanakan untuk penyebaran informasi untuk meningkatkan kewaspadaan terhadap Covid 19 
Jurnal SEMAR Vol. 10 No. 1 , hal. $45-50$

ISSN: 2745-4223 | Copyright (C LPPM Universitas Sebelas Maret Homepage: https://jurnal.uns.ac.id/jurnal-semar

\section{B. Edukasi Masyarakat Dari Berbagai Tingkatan Usia Dan Variasi Status Pekerjaan}

Kelas edukasi untuk pelajar dari tingkat SD sampai SMP, membuat grup di whatsapp untuk peserta kelas edukasi agar bisa memonitor kegiatan yang teah dilakukan, membuat perpustakaan kecil untuk memfasilitasi pelajar dalam menambah pengetahuan dan wawasan, membuat poster tentang pentingnya kewaspadaan terhadap Covid 19, bergabung dalam grup whatsapp warga dan membagikan informasi tentang Covid 19.

Relawan Online Corona merupakan suatu gerakan edukasi seputar virus corona dengan menggunakan media sosial instagram melalui gambar infografik yang di posting di Instagram masing-masing anggota relawan. Kegiatan relawan online corona ini dinilai dapat menjadi salah satu sarana dalam pengedukasian masyarakat dan sebagai sarana masyarakat dalam berperan menyebarkan edukasi tersebut. Relawan Online Corona membuka pendaftaran tanpa syarat dan terbuka untuk umum dengan beranggotakan lebih dari 1.000 anggota di media sosial Instagram. Selain memanfaatkan media sosial Instagram, kegiatan Relawan Online Corona juga mengadakan sesi diskusi dan tanya jawab menggunakan media sosial Whatsapp dan Telegram sehingga tidak hanya sebagai penyebaran informasi saja tetapi juga sebagai wadah untuk berdiskusi dan mengemukakan pendapat serta bertanya seputar Covid- 19.

Kegiatan Relawan Corona bergerak dengan cara menyebaran informasi kesehatan mengenai Covid-19 secara online. Terdapat 3 (tiga) kegiatan yang dapat diikuti setelah mendaftarkan diri sebagai anggota yaitu berbagi informasi terkini dan akurat seputar Covid- 19, diskusi online seputar Covid-19 di Telegram setiap hari bersama dokter dan diskusi online tematik setiap minggunya dengan tema tertentu.

Kegiatan menyebarkan informasi seputar Covid-19 dilakukan untuk menanggapi maraknya berita bohong atau hoaks mengenai Covid-19, selain itu juga sebagai sarana edukasi kepada masyarakat umum. Kegiatan ini dilakukan dengan me-repost konten Instagram @ relawanonlinecorona dalam bentuk gambar infografik dan video animasi. Selain itu, dapat juga dilakukan sesi tanya jawab di kolom komentar Instagram masing-masing anggota relawan sesuai dengan tema pembahasan yang termuat di infografik yang di posting.

Diskusi online seputar Covid-19 juga dilakukan sebagai edukasi kepada anggota relawan dengan menggunakan media sosial Telegram bersama dengan dokter sehingga sumber informasi yang diberikan akurat. Diskusi ini diberikan dengan sebagai sarana diskusi dan tanya jawab yang nantinya menjadi bekal kepada anggota relawan untuk menyebarkan informasi yang telah didapat kepada masyarakat umum. Selain itu juga terdapat diskusi dengan tema- tema tertentu tiap minggunya sesuai dengan permasalahan yang sedang hangat terkait dengan Covid-19.

Selama dilaksanakan program KKN ini, warga setempat semakin aware terhadap Covid- 19, bahkan setelah adanya pembagian masker beserta kartu edukasinya, warga setempat menggunakan masker tersebut dengan sebaik mungkin. Memasuki era "New Normal", aktivitas di tempat ibadah seperti masjid dan mushola sudah dapat dilakukan. Masyarakat sudah mulai sholat berjamaah di masjid dan mushola sesuai protokol kesehatan yangditetapkan pemerintah. Tujuan pembuatan poster cuci tangan dan pengadaan sabun cuci tangan ini dilakukan untuk mendukung protokol kesehatan yang ditetapkan pemerintah. Masjid dan mushola tidak menyediakan tata cara mencuci tangan dengan sabun, sehingga KKN Covid-19 akan menyediakan poster dan sabun cuci tangan sebagai bentuk dukungan kepada pemerintah terhadap protokol kesehatan di tempat ibadah dan merealisasikan gerakan pola hidup bersih dan sehat (PHBS), khususnya di dusun Paras, Banjarasri, Kalibawang, Kulon Progo. Membuat tempat cuci tangan yang bisa digunakan untuk umum. Tempat cuci tangan dibuat menggunakan ember. Setelah itu, tempat cuci tangan diberikan instruksi cuci tangan yang benar agar bisa dipraktekkan secara langsung oleh warga. Tempat cuci tangan diberikan di Desa Jogoyudan agar bisa dipakai untuk umum.

\section{c. Membuat poster dan banner tentang pentingnya kewaspadaan terhadap COVID 19.}

Dalam Pelaksanaan KKN merupakan program kerja yang bertujuan untuk mengingatkan warga tentang new normal dimana intinya adalah mamatuhi protokol kesehatan yang dianjurkan Pemerintah, wajib memakai masker, rajin mencuci tangan dengan sabun, menjaga jarak dan waspada penyebaran COVID-19. Karena dirasa masyarakat kurang begitu waspada dan berhati-hati mengenai penularan virus corona. 
Jurnal SEMAR Vol. 10 No. 1, hal. $45-50$

ISSN: 2745-4223 | Copyright (C LPPM Universitas Sebelas Maret Homepage: https://jurnal.uns.ac.id/jurnal-semar

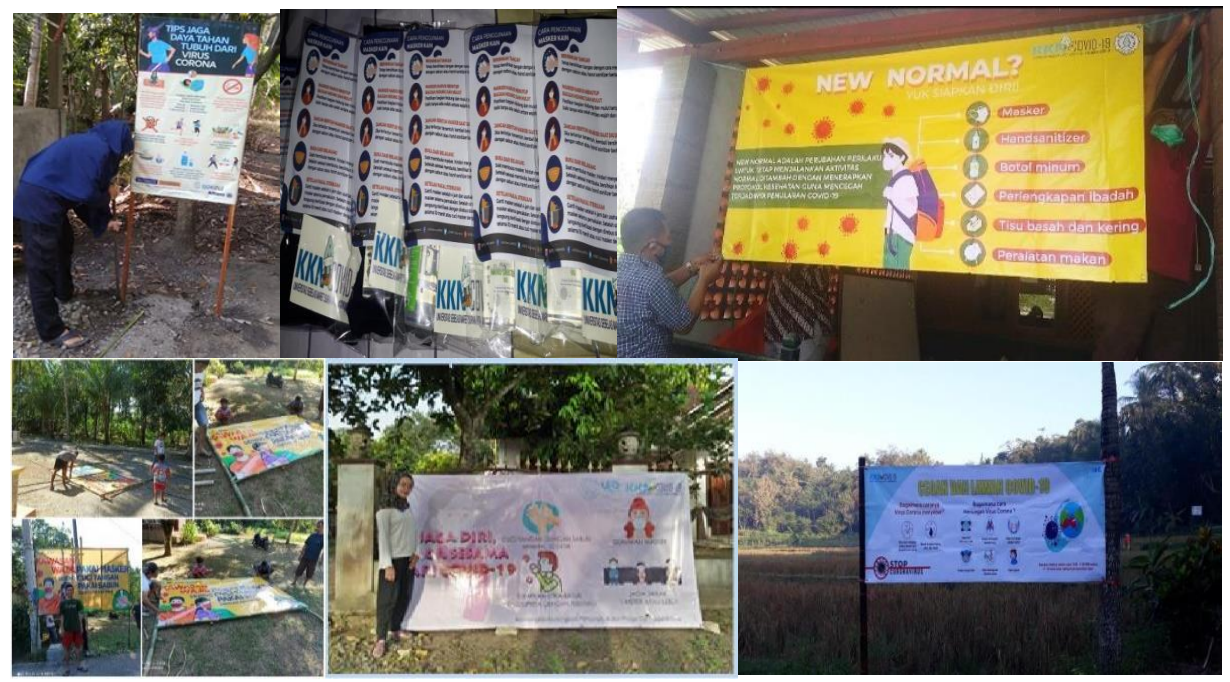

Gambar 2. Beragam poster yang telah dibuat oleh mahasiswa KKN di berbagai wilayah, yang dipasang diberbagai tempat yang strategis, agar masyarakat lebih paham mengenai kondisi pandemi covid 19

Banner dan Poster dipasang dilingkungan sekitar yang mudah terbaca seperti gapura masuk desa sebagai pusat masuknya warga. Poster ditempel di sepanjang jalan Desa dan area stategis. Poster-poster ini berisi konten bertema Covid seperti pentingnya memakai masker, physical distancing, dan new normal. Poster lain juga dibuat untuk memberikan penjelasan cara mengenali gejala yang diduga terinveksi oleh virus covid 19.

Membagikan artikel dari rumah ke rumah yang berkaitan dengan COVID 19. Artikel ini dibagikan ke rumahrumah warga. Kumpulan artikel-artikel ini dijadikan satu buku mini (buku saku). Artikel ini dibagikan bersamaan dengan pembentukan grup whatsapp warga dan membagikan informasi tentang Covid 19. Dalam grup warga, dikirimkan infografis tentang Covid-19. Respon dari warga baik dan merasa terbantu akan adanya pembagian materi mengenai COVID-19 kepada grup warga.

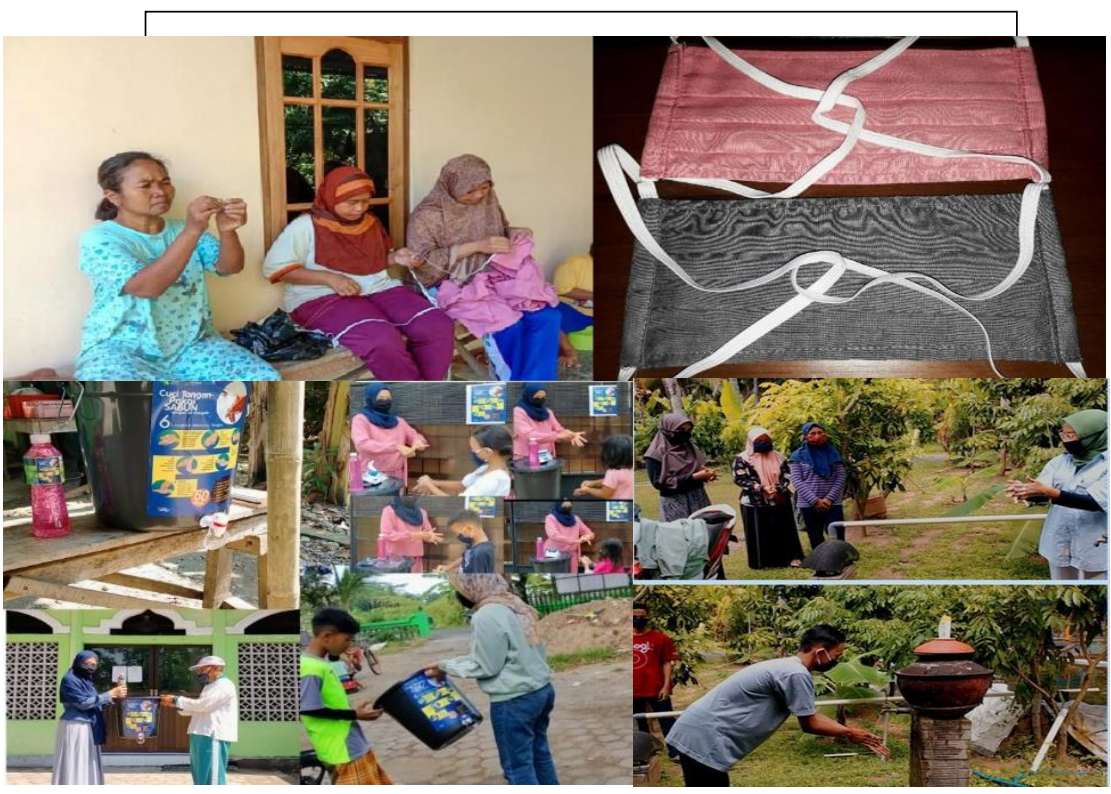

Gambar 3 . Pemberian fasilitas untuk pencegahan terjadinya kontak dengan virus covid 19 diantaranya dengan pembuatan hand sanitizer, tempt cuci tangan dan pembuatan hand sanitizer 
Jurnal SEMAR Vol. 10 No. 1 , hal. $45-50$ ISSN: 2745-4223 | Copyright (C LPPM Universitas Sebelas Maret Homepage: https://jurnal.uns.ac.id/jurnal-semar

Kegiatan lain yang dilakukan oleh para mahasiswa adalah membuatkan fasilitas untuk pencegahan terhadinya kontak dengan virus covid 19 diantaranya dengan pembuatan hand sanitizer dengan menggunakan alkohol dan bahan lainnya maupun hand sanitizer yang terbuat dari bahan herbal. Fasilitas lain yang dibuat oleh para mahasiswa adalah pembuatan masker yang standartnya mendekati dari standart masker kesehatan. Penggunaan masker secara benar juga telah dilakukan. Fasilitas lain yang dibuat oleh mahasiswa adalah pembuatan peralatan pencuci tangan yang dapat diletakkan di berbagai wilayah strategis dan dengan membuatnya dari berbagai bahan, mulai yang paling sederhana menggunakan kemasan bekas cat hingga menggunakan ember yang kemudian diberikan kran air.

\section{Kesimpulan}

Program kerja yang telah dilaksanakan oleh mahasiswa untuk masyarakat yang tinggal disekitar tempat tinggal mahasiswa pelaksana KKN diharapkan masih dapat dilanjutkan pelaksanaannya terutama pada saat kejadian Pandemi virus Covid 19 belum dinyatakan berakhir di wilayah Indonesia khususnya.

Selain itu, tujuan dari program KKN yang dilaksanakan juga dapat dikatakan mencapai target karena masyarakat lebih memahami dan sadar tentang bahaya penularan Covid-19, ditandai dengan masyarakat Pedukuhan VII Tayuban menjadi lebih berhati-hati dengan lebih menjaga jarak dan mengupayakan untuk tetap di rumah saja (stay at home) dan lebih tanggap terhadap situasi kondisi yang ada. Oleh karena itu, keberhasilan program KKN tentunya tidak terlepas dari peranan masyarakat yang dengan senang hati menerima program KKN yang telah dilaksanakan di daerahnya.

Dalam melaksanakan program KKN terdapat beberapa faktor yang dapat mempengaruhi keberhasilan suatu program, sebagai berikut:

1. Faktor Pendukung

a. Dukungan dari Ketua Dukuh Pedukuhan VII Tayuaban;

b. Dukungan dari orang tua, relawan desa, dan semua yang telah membantu terlaksananya program KKN dengan baik; dan

c. Respon positif dan antusiasme masyarakat Pedukuhan VII Tayuban dalam menerima dan ikut serta mensukseskan seluruh program KKN.

2. Faktor Penghambat

a. Sebagai mahasiswa pelaksana KKN UNS Era Covid-19 batch II sedikit mengalami kendala dalam melaksanakan program sesuai perencanaan dikarenakan jadwal pelaksanaan KKN berbenturan dengan jadwal kuliah daring, Ujian Akhir Semester;

b. Masyarakat yang berusia lanjut sulit menerima informasi yang disampaikan; dan

c. Pelaksanaan KKN UNS Era Covid-19 yang dilakukan individu terkadang dokumentasi tidak maksimal.

\section{Daftar Pustaka}

Febri, Suri Purnama. 2009. Pelatihan BUDIKDAMBER (Budidaya Ikan Dalam Ember) di Desa Tanah Terban Kecamatan Karang Baru Kabupaten Aceh Tamiang. Vol.3 No.1. hlm C112(112-117)

Kemenkes, 2020, Pedoman dukungan kesehatan jiwa dan Psikososial di era pandemi covid 19, Direktorat Jendral Pencegahan dan Pengendalian Penyakit, Subdit Masalah Penyalahgunaan Napza Direktorat P2MKJNMaret 2020

Kemenkes, 2020, Pedoman Pencegahan dan Pengendalian Corona Virus Desease (Covid 19), Direktorat Jendral Pencegahan dan Pengendalian Penyakit, Maret 2020

Kemenkes, 2020, Protokol area publik dan transportasi, , Direktorat Jendral Pencegahan dan Pengendalian Penyakit, Subdit Masalah Penyalahgunaan Napza Direktorat P2MKJNMaret 2020 